\title{
Legal Aspects of Living Arrangement Responsive and Sustainable
}

\author{
Ashari $^{1}$ \\ Muhaimin $^{2}$ \\ GDH Wibowo 3 \\ H. Adolf 4 \\ 1 Student of Doctoral Law Study Program, Postgraduate Program, Mataram University, Indonesia \\ 2 Lecture of Law Faculty Mataram University, Indonesia \\ 3 Lecture of Law Faculty Mataram University, Indonesia \\ ${ }^{4}$ Lecture of Law Faculty University of Padjadjaran, Bandung, Indonesia
}

\section{Doi:10.5901/mjss.2017.v8n1p71}

\section{Abstract}

The purpose of this research is to: (1) analyzing the principles and substance of the relevant spatial responsive and sustainable; (2) analyzing the institutional and mechanism/procedure as what to support spatial responsive and sustainable; (3) finding a model of spatial perspective responsive and sustainable. For further research of a normative law (legal research) by using a philosophical approach, the statute approach, the conceptual approach and the historical approach. The results obtained are: First, the spatial arrangement of the elements is part of the Environment. Therefore, the principle or principles in the management of the Environment shall apply mutatis mutandis also applies to the arrangement of space; second, the substance of the arrangement of space includes the planning, utilization, control utilization of space. The elements in the content material are an organic unity that cannot be separated from one to another; Third, institutional spatial planning there is still a dependent institutional, structural or still the subordination of the other institutions. In addition, mechanisms or procedures in spatial stats still lead to Institutional responsive spatial planning and sustainable (top down approach).

Keywords: Spatial planning, responsive and sustainable

\section{Introduction}

In this study, there are three problems in the spatial plan to be lifted. First, the philosophical problems that occur in the spatial plan are the principle of disobedience in the regulation of spatial planning. Responsive and sustainable principle was not defined in the rule of law as it should be. The fact disobedience on the principle spatial planning arrangement mentioned above are marked by how many cases of violations of spatial planning that impact on spatial planning of policy shifts, such as:

a. The occurrence of land conversion that continuously so that the use of space be not as intended, and harm the interests of the public in accessing social, cultural, economic.

b. Environmental damage ecologically and very harmful people, who become targets of the spatial planning, like rob (flooding), floods and landslides, damage to protected areas, and so forth.

c. The emergence of social conflicts that are structural land between citizens who were subjected to spatial planning with the Regional Government, including between the community and the employers as a result of the use of land space that does not function as it should. The land conflict was caused by their efforts to "expropriation" of land that had been occupied, processed and controlled by the community to serve as the desired region by the owners of capital, such as for industrial, residential, tourism, and so forth.

It is another thing that can be viewed from the philosophy of law policy formulation that has been included in the 
Regional Regulation (PERDA) there was a trend has begun to lead to capitalistic economic considerations. Theoretically, a shift in the philosophy of spatial planning policies towards improving the capitalistic economy can be explained from the theory of cybernetics as stated by Talcot Parsons, where the economic subsystem with high energy will always seek to control all spatial planning policies toward fulfilling the interests of capitalistic economy. The position of the economic subsystem will be stronger if it received strong support from the political subsystem.

Second, the emergence of a sociological problem behavior urbanization are likely to affect the development of settlements needs growing rapidly impacting the lack of green open space (RTH) and farmland for the production of foodstuffs on the wane due to conversion of land into residential and non-agricultural employment, in addition to the presence of norm setting in the spatial plan were not implemented. As a result in the implementation spatial planning was occurred uncertainty for policy makers which resulted in a decrease in the quality of space and environment and detrimental to the public.

Third, juridical problem in spatial planning that there were inconsistencies in the settings related to spatial planning. Aspects adjustment of spatial planning (RTRW) is inconsistent with the implementation and controlling space utilization. Many licenses issued are does not match with the spatial plan. The fact that there was at this time that ratification of changes to a Regional Regulation (PERDA) Spatial Plan (RT/RW) had a tendency as a result of the land prohibited from becoming to be authenticated (legalized) in a regulation.

Furthermore, spatial planning, decentralization is now actually there are some districts in West Nusa Tenggara (NTB) is still not up to formulate the preparation of Spatial Plan (RT/RW) which is responsive and sustainable, and often do not pay attention to the principle of law in the establishment of legislation which is good enough in the regulation spatial planning responsive and sustainable.

The goals to be achieved in this study are: First, to analyze the principle or principles of law that are relevant for spatial planning which is responsive and sustainable; Second, to analyze the material content of spatial planning which is responsive and sustainable; and Third, to analyze perspectives on spatial planning which is responsive and sustainable.

\section{Research Methods}

The research type that has been done is a normative legal research is research that examines and analyzes legislation, legal principles and legal norms in order to obtain clear description of the legal aspects of spatial planning that is responsive and sustainable, despite this study is normative but also supported by field data (empirical).

This study uses various approaches, with the aim to obtain information on the various aspects of the issues being examined. To solve the problem of the subject in this study, it has been used approach:

a. Philosophical approach is the approach taken to examine legislation and regulations concerning local government, especially with regard to Legal Aspects of Spatial Planning and Sustainable Responsive to be viewed from the side of philosophy.

b. Statute approach that is the approach taken to examine legislation and regulations relevant to the legal issues are being addressed.

c. Conceptual approach is an approach that departs from the views and doctrines that developed in the jurisprudence (Peter Mahmud Marzuki, 2006).

d. The sources of the data in this study come from:

e. Primary data (primary sources). Primary data is data that is authoritative means to have authority, such as legislation, official records or reports in the legislation, and the Verdict, relating to the Legal Aspects of Spatial Planning that Responsive and Sustainable.

f. Secondary data (secondary sources), the data provide an explanation of the primary data as the opinion of the experts, the opinions of scholars, articles, scientific works in law, newspapers, internet and other supporting data materials.

\section{Results and Discussion}

\subsection{Relevant Legal Principles to the Spatial Planning that is Responsive and Sustainable}

To realize the spatial planning responsive and sustainable while ensuring no disruption of public interest broadly (public interest), it would require a concept of spatial planning which aims for all resources and natural riches contained therein can be managed and utilized optimally by applying the principles of law that are relevant for spatial planning and sustainable responsive as stated in Article 2 of Law No. 26 Year 2007 on spatial planning (ibid, 46), namely: 

a. The principle of integrity
b. The principle of compatibility, harmony, and stability
c. The principle of sustainability,
d. The principle of usability and successfully

\subsection{The Protection Principles and Environmental Management in Spatial Planning Regulations}

Spatial planning can be said to have an important role in protection efforts and managing the environment. For that also, then talk about the principles of law in spatial planning that is responsive and sustainable, according to the researchers cannot be separated from the aspect of environmental protection and management considering the current environmental conditions have started worrying in the sense that the quality of the environment tends to decrease and has threatened the survival of life of humans and other living creatures. For that needed protection and environmental management seriously and consistently by all stakeholders to maintain the continuity of the carrying capacity and environmental carrying capacity.

Similarly, according to the researchers, the Law No. 32 of 2009 on the Protection and Environmental Management have entered the foundation philosophy about the concept of sustainable development and environment in the context of economic development.

Related instrument of law enforcement can be reached through three (3) ways, among others, namely:

a. Law Enforcement Administration (licensing, the State Administrative Court)

According to researchers, environmental management can only be successful promoting sustainable development if the government administration to function effectively and comprehensively.

b. Enforcement of Criminal Law instruments

Enforcement of administrative sanctions is the frontline in the enforcement of Environmental Law (primumremedium). In this case, if the administrative sanction is considered ineffective, then used means of criminal sanctions as the ultimate weapon (ultimumremedium).

c. Enforcement Civil Law instruments

Instruments in Civil Law aim to claim damages and / or certain legal actions as a result of the actions that cause pollution and environmental destruction (Abdurrahman, 2001).

Besides Right to Sue may be proposed by the Government and Local Government, the lawsuit may also be filed by the public and environmental organizations may be class action lawsuit. If it is known that people suffer as a result of pollution and/or destruction of the environment in a way that affects the basic livelihood of society, the government agency responsible in the environmental field can act in the public interest. Administrative lawsuit is also provided for in Article 93 of Law No. 32 of 2009 on the Protection and Management of Environment and procedures for filing an administrative lawsuit refers to the procedural law of the State Administrative Court (Administrative Court).

\subsection{Institutional and Support Mechanisms of Spatial Planning that Responsive and Sustainable}

\subsubsection{The Concept of Institutions and Institutional}

The use of the term "institution" in the English language literature, or the terms of "institutions" and "institutional" in the Indonesian language literature tend to be inconsistent and there is no common understanding among experts, as well as the concept of "organization". The most frequent mistake is to translate "institution" to "institutional", while the "institution" is defined exactly as "organization".

Related institutional terms, according to researchers tend to have an emphasis on the following five aspects, are:

1) First, institutional relates to something permanent, it's become permanent, because it is deemed rational and unconscious needs in life. Norms and ordinances that are fixed are located within an institution.

2) Second, institutional deals with the abstract things those determine behaviour. These abstract things roughly the same as what Cooley called the public mind, or 'ideal form of culture' by Koentjaraningrat, or cultural according to Johnson. In broad outline, it is composed of values, norms, laws, regulations, knowledge, ideas, belief and morality.

3) Third, related to the institutional behaviour, or a set of mores (code of conduct), or how to act steady running in society (establish a way of behaving).

4) Fourth, the institution also emphasizes the patterns of behaviour that are approved and have sanctions.

5) Fifth, institutions are the standard ways to solve the problem. The emphasis is on the ability to solve problems. 
According to the researchers, from the fifth emphasis on the above understanding, it appears that the 'institutional' has a primary attention to the behavior pattern where most come norms adopted. Institutional centered on goals, values or social needs are primary. Furthermore, institutional stressed to a procedure, a certainty, and guides to do something.

\subsubsection{Legal Aspects of Institutional and Supporting Mechanism of Spatial Planning that Responsive and Sustainable}

According to researchers, the need for the principle of government and social institutions in supporting spatial planning responsive and sustainable, which refers to decentralization efforts, among other things: First, it should be transparency in the arrangement of space, democratization in decision-making and policy; Second, there must be a government accountable to the public; Third, efficiency and effectiveness in the management of aspects of spatial development; Fourth, the creation of acceleration and precision of formulation, implementation and control of aspects of spatial development, the realization of justice for every society and its institutions. It is expected that all four principles above can support the creation of good spatial planning management.

Implementation of development, especially physical development does not always go according to the spatial plan that has been set. There are three (3) strategic issues in the field of spatial successfully mapped by the Directorate of Spatial Planning and Land Affairs, Deputy Regional Development and Autonomy, Ministry of National Development Planning (BAPPENAS) related to spatial planning policy and national land management from 2015 to 2019 , are: ${ }^{1}$

1) The ineffectiveness of the institutions of spatial planning;

2) The utilization and control of spatial planning has not been effective;

3) Spatial Planning (RTRW) has not been used as a reference development of various sectors.

The researcher adds that the three strategic issues in the field of spatial, and then rise to a violation or deviation utilization of space, this time tend to be caused by various factors, among others: the technical, operational, administrative / political, and market developments, which are then narrowed down into a number of problems in the field spatial, are:

1) The amount of legislation related to space that needs to be synchronized;

2) Human Resource Competency organizers inadequate spatial planning;

3) Lack of institutional capacity and coordination in the field of spatial planning;

4) Unintegrated indicative program in Spatial Planning (RTR) with sectorial development plans and programs;

5) The high quality variation of Spatial Planning;

6) Still weak law enforcement in the implementation of Spatial Planning;

7) Not yet operational control device which is clear and complete; and

8) There is a shortage of spatial information system for monitoring and evaluation.

Various problems in the implementation of space utilization control according to researchers is closely associated with the issue of institutional effectiveness itself in control of spatial planning. To that end, the institutional aspect is very closely related to spatial planning authority. Based on Government Regulation No. 38 of 2007 on the Division of Government Affairs between the Government, Provincial Government, and the Government of Regency/City, spatial planning is a concurrent governmental affair ${ }^{2}$ is shared between governments. In order to create an orderly space in accordance with the spatial plan, the space utilization control according to researchers must be integrated and integrated conducted by competent authorities in accordance with the authority.

Based on the fact the problems and strategic issues facing the field of spatial, Researchers then according to one of the strategic environment that need to be considered in the field of spatial development is the strengthening and improvement of internal capacity spatial field that includes the functionality of activities setting, development, implementation and oversight by strengthening the role of the Regional Spatial Planning Coordinating Board (BKPRD) as a body that is ad-hoc in the area that has the function of helping the implementation of tasks Governor / Regent / Mayor

${ }^{1}$ Policy Direction of Spatial Planning and National Land Management 2015-2019. Indonesian Ministry of National Development Planning (BAPPENAS). Jakarta, December 6, 2013, p.14. Directorate General of Spatial Planning. Ministry of Agrarian Affairs and Spatial Planning.

${ }^{2}$ Concurrent Government Affairs is a government an affair is shared between the Central Government, Provincial Government and the Government of Regency/City. Concurrent Government Affairs submitted to the Region is the basis for the implementation of regional autonomy. Concurrent Affairs is divided into Regional authority of Government Affairs and Government Affairs Mandatory Options. While the mandatory affairs were divided into basic services and non-basic service. Mandatory government affairs and become a Basic Service there are six matters, shall include: education; health; public works and spatial planning; housing and residential areas; peace, public order, and the protection of society; and social (See: Article 12 of Law Number 23 Year 2014 on Regional Government). (See: Article 12 of Law Number 23 Year 2014 on Regional Government). 
in coordination of spatial planning that includes coordination in the planning, utilization and control of space utilization, both preventive violations utilization of space, nor that is curbing violations. Therefore, when referring to the effective role of the Regional Spatial Planning Coordinating Board (BKPRD) in the spatial planning process, then it should have required more technical guidelines related to the mechanism controlling spatial utilization.

The above conditions according to researchers, has hinted that in order to realize the creation of development "orderly room" in the control space utilization related to the preparation of detailed spatial planning documents (RDTR) in the spatial management mechanism Regency/City then it needs to be supported by institutional aspects in the region are realized with the BKPRD that serves as a coordinating body in the field of spatial planning.

\subsection{The Perspective of Spatial Planning Model that Responsive and Sustainable}

\subsubsection{Spatial Planning that Responsive and Sustainable Based Integrative Law}

Spatial planning in the view of researchers actually not only the spatial planning alone, but covers also the use of space and control space utilization.

The most important aspect of spatial planning in order to realize a responsive and sustainable based integrative law is that the spatial arrangement in principle an interdisciplinary science, so in this case should be grown is a mind-set that is comprehensive and integrated.

According to researchers, the setting and arrangement of space that is responsive and sustainable should require an integrative law, are the synthesis of analytical jurisprudence, interpretation realistic from the point of psychological, social, and cultural facts, concoction-value of the doctrine of natural law. Explore a variety of ideas or the material strength of the substantive law of life and reflect the relationship between individual and depend on one to another.

\subsubsection{Spatial Planning Models that Responsive and Sustainable}

According to researchers, in order to realize a model of spatial responsive and sustainable, particularly in the province of West Nusa Tenggara (NTB), then in the spatial planning process should put the concept of environmental balance. In this case, focus area utilization for various activities the use of an area of focus for the activities which adjusted to the carrying capacity of the environment. Considering the pattern of development activities were generally has consideration not only the physical, but also social and cultural. Even elements of any local wisdom have always been one of the principal references in formulating measures of sustainable development to answer the challenges of advancement.

In this context, according to the researchers, spatial planning based on environmental balance plays an important role as a tool for translating the principles of sustainability into the organization and management of the built environment. For that same then according to the researchers, the first step that must be done to realize a model of spatial planning and sustainable responsive enter formulas normative strengthen global awareness of the serious impact of global climate change at this time become an international issue. In this case according to the researcher, the model of spatial responsive and sustainable as a system of spatial planning, space utilization and control of space as outlined in the Regional Regulation (Perda) on Spatial Planning (RTRW) should prioritize aspects of the calculation of a disaster or a responsive disaster, By considering the correlation between the impact of global climate change with the occurrence of natural disasters.

Furthermore, the model of spatial responsive and sustainable as outlined in the Regional Regulation (PERDA) on Spatial Planning (RTRW) expected to depart from the essence of spatial planning based on the principles of sustainability because it is considered instrumental in producing the quality of urban built environment that can be achieved by creating an environment that is responsive to the dynamics of socio-cultural, ecological environment, physical requirements and economic demands, in addition to be able to attract residents and citizens concern spatial planning objectives, as well as providing the convenience in the activity.

Therefore, the model of spatial responsive and sustainable as outlined in the Regional Regulation (PERDA) on Spatial Planning (RT/RW) according Researchers can be developed into some of the principles of physical development, as follows:

1) Environment and street / urban infrastructure was good, healthy, supplemented with elements of complementary urban (urban amenities), for example: the city park, the green open space (RTH), and building the scale, proportions, dimensions, standards and good composition;

2) Density determination is the density of urban areas, that for continuity of activities/functions that need to be based on the consideration of environmental carrying capacity; 
3) A unified integration between different events / activities, such as residential housing, work, shopping, recreation, spiritual life, and others;

4) Structuring and placement of buildings (layout masses and building code) based on the principles of planning/design which is good and right; and

5) Typo-morphological diversity of buildings and open spaces are interconnected and related to the ease of accessibility and achievement.

\section{Conclusions and Recommendations}

\subsection{Conclusions}

Spatial planning is a part of elements of the Environment. Therefore, the principle or principles in the management of the Environment shall apply mutatis mutandis which also applies to spatial planning. As for the substance of the normative spatial planning includes planning, utilization, control space utilization is an organic unity that can not be separated from one to another. But in reality the above norm is not being implemented properly, resulting in inconsistencies in the planning, utilization and control space utilization.

The institutional of spatial planning that exist now days are still the dependent institutional, the structural or still the subordination of the other institutions. In addition, mechanisms or procedures in spatial stats still lead to spatial planning that were responsive and sustainable (top down approach).

The settlement model of the space currently in implementation has not reflected the principles of transparent, effective and efficient. In determining the choice or policy priorities in the field of spatial planning tends to not be separated from the interests and demands of the various interest groups as well as the less accommodating the substance and the context surrounding the spatial planning policy priorities to be taken so that it becomes difficult to realize spatial responsive and sustainable.

\subsection{Recommendations}

Application of the principles and substance of the spatial planning that is responsive and sustainable should be implemented consistently and responsibly so that the Government in the Region is expected to be a pioneer in efforts to achieve environmental sustainability.

Is necessary to develop an independent agency in the spatial field that is not subordinated, which is able to perform tasks across administrative and across sectors. For that, we need a mechanism/procedure in the spatial planning process that is holistic, integrated, responsive, aspirational and accommodating that facilitate the involvement of participation of the active role of all development actors (stakeholders) in the development plan considering that the phenomenon of spatial in the current era of globalization that is very complexes that are expected to realize spatial responsive and sustainable.

To realize a model spatial planning responsive and sustainable will require parameters or indicators, among others: First, the addition principle of responsive and sustainable, it also takes the other principles that are operational as a supporter, namely: the principle of transparent, effective, efficient and easy to implement; Second, Institutionally needed that independent institutions that have great authority to regulate and supervise the implementation of spatial set. Third, the spatial planning procedures are bottom-up must be a shared commitment to be realized in reality. It is necessary for role-sharing between the various stakeholders for the purpose of spatial planning, starting from the planning, utilization and control of space utilization can be monitored (Controlling).

\section{References}

Abdurrahman. (2001). Law and Environmental of Indonesia. Jakarta. Postgraduate program, Faculty of Law, University of Indonesia. Ahmad Husni M.D and Bambang Sugiono. (2001). Legal Approach Strategy in Solving Environmental Problems in Law and Environment in Indonesia. Jakarta. Postgraduate program, Faculty of Law, University of Indonesia.

Daniel E. Hebding and Leonard Glick. (1994). Introduction to Sociology: a Text with Readings. Pilipina. Hill Inc and Philipine Graphic Art Inc.

Hardjowigeno, S. (1999). Land Suitability and Land Use Planning. Bogor. Soil Department, Faculty of Agriculture, Bogor Agricultural University.

Indonesian Ministry of National Development Planning (BAPPENAS). Policy Direction of Spatial Planning and National Land Management 2015-2019. Jakarta . Jakarta, December 6, 2013. Directorate General of Spatial Planning. Ministry of Agrarian 
Affairs and Spatial Planning.

Laws of the republic Indonesia. (2007). Law No. 26 Year 2007 on Spatial Planning

Laws of the republic Indonesia. (2014). Laws No. 23 Year 2014 on Regional Government

Masri, R.M. (2008). Study of Environmental Change in the bad zone for Housing. Bogor Agricultural University Doctoral Dissertation: unpublished.

Mellville C. Branch. (1996). Comprehensive Urban Planning, Introduction and Explanation, Second printing, Translators Bambang Hari Wibisono, Editor Achmad Djunaedi. Yogyakarta. Gadjah Mada University Press.

Mitchell, G. Duncan. ed. (1968). A Dictionary of Sociology. London . Routledge and Kegan Paul.

Mochtar Kusumaatmadja. (1975). Legal Development in the Context of National Development. Bandung. Bina Cipta.

Peter Hall / Pfeiffer. (2000). Urban Future 21. London. A Global Agenda for Twenty-First Century Cities.

Philipus M. Hadjon. (1994). Assessment of Dogmatic Legal Studies (Normative). Articles in Yuridika Magazines, No. 6 Year I X November-December 1994. Surabaya. Airlangga University Press.

Peter Mahmud Marzuki. (2001). Legal research. Law Journal of Yuridika. Vol. 16 No. 1 March-April 2001. Surabaya. Airlangga University Press.

Peter Mahmud Marzuki. (2006). Legal research. Jakarta. Kencana Prenada Media Group.

Regional Development Planning Agency of NTB (Bappeda). (2006). Spatial Plan of West Nusa Tenggara province Years 2006-2020. Mataram. Regional Development Planning Agency of West Nusa Tenggara.

Scott, Richard W. (2008). Institutions and Organizations: Ideas an Interest. Third Edition. Los Angeles, CA. Sage Publication.

Soemardjan, Selo and S. Soemardi. (1964). Sprig Flower of Sociology (set of paper). Jakarta. Publisher Faculty of Economics, University of Indonesia.

Suparlan, Parsudi. 2004. Community \& Urban Culture: Anthropological Urban Perspectives, First Edition, Jakarta. Police Science Research Development Foundation.

Uphoff, Norman. 1986. Local InstitutionalDevelopment: An Analytical SourcebookWith Cases. USA. Kumarian Press. Cornell University. World Commission in Environment and Development, 1987. Our Common Future. New York. Oxford University Press. 